\title{
Pharmacological Potential of Vinegar Tree Species: a study conducted by the scientific and technological prospecting techniques
}

\author{
Potencialidades Farmacológicas da Espécie Vinagreira: um estudo \\ realizado por meio das técnicas de prospecção científica e tecnológica
}

\author{
Katiury Castro Cavalcante ${ }^{1}$ \\ Gladson Diniz Pinheiro ${ }^{1}$ \\ Álvaro Itaúna Schalcher Pereira ${ }^{1}$ \\ Oswaldo Palma Lopes Sobrinho \\ Layane Bastos dos Santos ${ }^{3}$ \\ Francisco Adelton Alves Ribeiro ${ }^{1}$ \\ ${ }^{1}$ Instituto Federal de Educação, Ciência e Tecnologia do Maranhão, Campus Codó, Maranhão, MA, Brasil \\ ${ }^{2}$ Instituto Federal de Educação, Ciência e Tecnologia Goiano, Campus Rio Verde, Goiano, GO, Brasil \\ ${ }^{3}$ Instituto Federal de Educação, Ciência e Tecnologia do Maranhão, MA, Brasil
}

\begin{abstract}
This research aims to describe using techniques of scientific and technological forecasting information about the vegetable species Hibiscus sabdariffa L. present on the banks of national and international data evaluating its chemical aspects and pharmacological/medical applications. For this, searches were conducted in scientific data bases Web of Science and Scopus and patent banks: National Institute of Industrial Property (INPI) and World Intellectual Property Organization (WIPO). The bases studied, Scopus and WIPO were obtained which results in more number of publications and patents filed. Nigeria was the country that published on hibiscus in the 2007-2017 period, followed by India and Taiwan. China was the country with the highest number of registered patents, holding $53 \%$ of the results. Brazil has a low proportion in the number of deposits. Documents found in the WIPO classified into sections $\mathrm{A}$ and $\mathrm{C}$ of the IPC classification, with most of them included in subclass A61K (preparations for medical, dental or hygienic purposes).
\end{abstract}

Palavras-chave: Hibiscus. Chemical compounds. Patent.

\begin{abstract}
Resumo
Este artigo descreve utilizando técnicas de prospecção científica e tecnológica informações sobre a hortaliça da espécie Hibiscus sabdariffa L. presentes nos bancos de dados nacionais e internacionais avaliando seus aspectos químicos $e$ aplicações farmacológicas/medicinais. Para isso, foram realizadas buscas nas bases de dado científicas Web of Science e Scopus e nos bancos de patentes: Instituto Nacional da Propriedade Industrial (INPI) e World Intellectual Property Organization (WIPO). Das bases estudadas, a Scopus e WIPO foram as que obtiveram mais resultados em número de publicações e patentes depositadas. A Nigéria foi o país que mais publicou sobre o hibisco no período de 2007-2017, seguida da Índia e Taiwan. A China foi o país com maior número de patentes registradas, detendo 53\% dos resultados. O Brasil apresentou uma baixa proporção no número de depósitos. Os documentos encontrados na WIPO se enquadraram nas seções $\mathrm{A}$ e $\mathrm{C}$ da classificação $\mathrm{CIP}$, com a maioria deles inclusos na subclasse $\mathrm{A} 61 \mathrm{~K}$ (preparações para finalidades médicas, odontológicas ou higiênicas).
\end{abstract}

Keywords: Hibisco. Compostos químicos. Patente.

Technology Area: Technology Prospects for Specific Subjects. 


\section{Introduction}

Biodiversity is an asset of nature that serves as basis for many economic activities, industrial, scientific, food, pharmaceutical and other applications essential to maintaining the quality of life on our planet. In this sense, Brazil is the country holding the most abundant flora of the globe, with about $15 \%$ to $20 \%$ of the recorded species. In addition, Brazil stands out also by the presence of various biomes (Amazon, Atlantic Forest, Cerrado) with significant amounts of endemic plant species (CORADIN; SIMINSKI; REIS, 2011).

In this context, it highlights the species Hibiscus sabdariffa (also known by hibiscus, okra-sour okra-pink poppy Rosélia, vinegar), which is a herbaceous plant of Malvaceae family of powerful medicinal potential, which originated in India and it was brought to Brazil by way of the slave trade in the nineteenth century (LORENZI; MATOS, 2002). Studies see been developed with hisbisco assess the fiber content, vitamin $\mathrm{C}$, phenolic compounds, anthocyanins, among other components present in the plant, which is conferring antibacterial, antioxidant, anti-inflammatory, anti-diarrheal, anti-hypertensive, diuretic (ALI; WABEL; BLUNDEN, 2005; LIN, 2007; LIU, 2006; HERRERA-ARELLANO, 2007).

The hibiscus seeds are also rich in polyphenols such as $\beta$-sitosferol and $\alpha$-tocopherol (MOHMMED et al., 2007) that fight free radicals in the body, thus preventing cancer and other diseases that affect human health. The cup plant is valued in the textile, food and pharmaceutical industry, as it is rich in organic acids that help, for example, in the preparation of teas, wine, vinegar, jam, popsicles and other products with high nutritional value (CARDOSO, 1997). Prospective studies this is a powerful tool in the collection, analysis, interpretation and add value to this information, it is possible to preserve the collective knowledge and develop strategies to achieve progress in technological innovation (GALVÃO, 2009). It adds that this research line developed here, is to assist in identifying potential opportunities and future needs in the technical and social environment culminated in technological and scientific advances in the use of Hibiscus sabdariffa.

Thus, this research is based on the use of scientific and technological prospecting for mapping information developed around the Hibiscus sabdariffa L. species by analyzing their potential pharmacological and evolution of technological competencies in national and international databases. It is intended to collaborate with the research of innovation through information collected on the main studies of $H$. sabdariffa species in the area of Chemistry and Pharmacology at the equivalent of 2007-2017; and technical development levels achieved with the plant applications in the industrial and social environment.

\section{Methodologic}

This survey was conducted from february to march 2018. The scientific prospecting quantitative aspect was developed exclusively from articles published on the basis of data present in the Journals Portal CAPES (Higher Education Personnel Improvement Coordination) and for qualitative review was used in addition to these publications, works of other species such as monographs, dissertations and PhD, books and manuals. We selected articles in Scopus and Web of Science - Main Collection (Clarivate Analytics) using descriptors like the genre (Hibiscus), the species (Hibiscus sabdariffa L.) and common name in the country (vinegar). The terms mentioned above were surveyed in the "title, abstract and keywords" which in Portuguese refers to research fields including title, abstract and keywords, respectively. 
During the data collection was established a period corresponding to the last ten years of scientific publications (2007-2017). Other years that drew attention to the number and relevance of the research have been cited in the course of work. Regarding the type of document, was prioritized only articles and abstracts in Portuguese, English and Spanish. Thus, we selected all journals published in Italy and abroad magazines. To achieve the objectives of this research scientific monitoring was delimited to the following areas: 1 - Pharmacology, Toxicology and Pharmacy (Pharmacology, Toxicology and Pharmacy) and 2 - patent registration in national and international databases. However, some journals applied in other areas of knowledge were mentioned in the results and discussions to complement the work.

After the data already filtered, only analyzed the articles and data base of abstracts with the highest number of publications on the species Hibiscus sabdariffa, where they were organized and stored for later be correlated and classified into specific software (Microsoft Excel ® 2016). Then the graphs and charts generated allowed the characterization of patents as: a) Annual evolution of technologies developed in the last ten years; b) major institutions/companies holding; c) depositors countries.

To complete the analysis of patents, they were characterized according to criteria adopted by the IPC (International Patent Classification). At that time, he expounded to the sections, classes and groups, as well as subclasses and subgroups which these documents are framed described also the latest technological inventions of the Hibiscus sabdariffa L. species.

\section{Results and Discussion}

The articles and abstracts that followed the search criteria was collected and grouped according to the keyword and the data base searched as shown in Table 1. It is noted a difference in the number of records in both the scientific basis both of documents related to Hibiscus genus as documents directed to chemical/pharmacological studies of the species Hibiscus sabdariffa L. in Web of Science were found 630 periodicals, of which approximately $35.9 \%$ of this total are works related to the species Hibiscus sabdariffa L.

Table 1 - Total publications in scientific databases in the period from 2007 to 2017

\begin{tabular}{ccc} 
KeY wORDS & WeB OF SCIENCE & Scopus \\
Hibiscus & 402 & 1,454 \\
Roselle & 226 & 610 \\
Vinegar & $2^{*}$ & $3^{* *}$ \\
Total & 630 & 2067 \\
\hline
\end{tabular}

Note: * Articles published only in the year 2017. ** Articles published between the years 2016-2017.

Source: Prepared by the authors of this article (2018)

For the Table 1 information analysis were selected only articles/abstracts found in the Scopus database that were related to the scientific name of the plant in question. Thus, 2,067 journals published in this source, about 610 were analyzed graphically as the area of knowledge, scientific collections, authors, countries and years. Of the total of document 546 (89.5\%) of product type and are $64(10.5 \%)$ corresponded summaries. 
In order to describe aspects of the chemical and pharmacological/medicinal property of the species Roselle, only 83 studies were filtered to literature review. In this sense, in Figure 1, the first graphical analysis included the main areas of knowledge of the publications, which were: Medical (267), Pharmacology, Toxicology and Pharmacy (211), Biochemistry, Genetics and Molecular Biology (178), Agriculture and Science biological (175) and Chemistry (157). Notes the percentage value of each of these areas, especially medicine representing $27 \%$ of total publications.

Figure 1 - Number of publications $H$. sabdariffa species per area of knowledge

$$
\begin{aligned}
& \text { Medicine } \\
& \text { Pharmacology, } \\
& \text { Toxicology and } \\
& \text { Pharmacy } \\
& \text { Biochemistry, Genetics } \\
& \text { and molecular biology } \\
& \text { Agriculture and } \\
& \text { Biological Sciences } \\
& \text { Chemistry }
\end{aligned}
$$

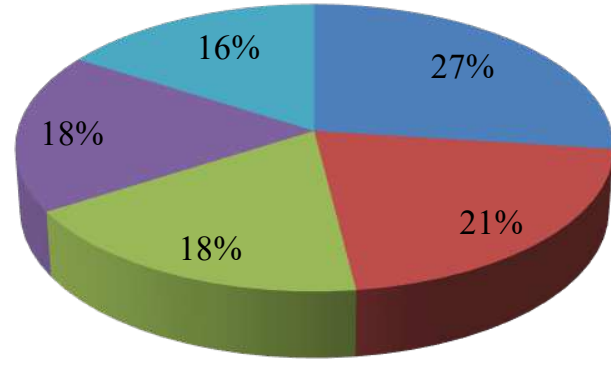

Source: Prepared by the authors of this article (2018)

During the predetermined period for data collection were recorded 159 published scientific collections of the species in Scopus Roselle. In Figure 2, they are represented some of these collections, highlighting the Journal of Ethnopharmacology (29), Food Chemistry (25), Journal of Agricultural and Food Chemistry (14), Pakistan Journal of Nutrition (13) and Journal of The Science of Food and Agriculture (12). Of the 29 articles published in the Journal of Ethnopharmacology, all are framed on the axis of Pharmacology, Toxicology and Pharmacy. It is a journal with an impact factor 2,981 and covers interdisciplinary work with ethnopharmacological approach, ethnobotany or biochemistry to the study of indigenous drugs. Thus, the review articles that address several pharmacological and toxicological activities of plants are also included in this collection.

Figure 2 - Number of species $H$. sabdariffa publications for scientific collection

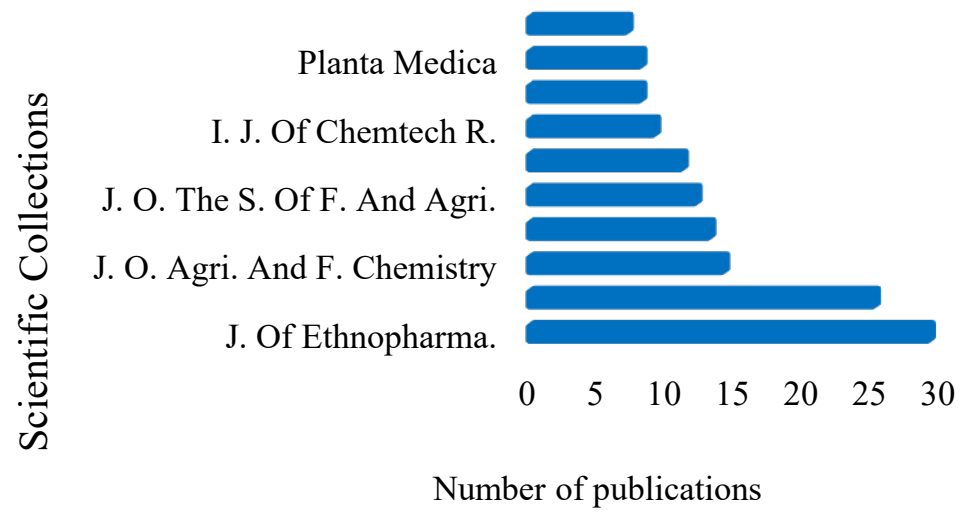

Source: Prepared by the authors of this article (2018) 
The second place in the ranking (Food Chemistry), with the number of publications was also significant to the previous collection, features 4,529 impact factor and works with "original research papers on the progress of chemistry and biochemistry of foods or methods/analytical approaches used" (ELSEVIER, 2018). Therefore, among the criteria used by this journal, which fit over the line of research on Roselle species are: a) presence of bioactive components such as antioxidants; b) chemical, nutritional, microbiological, sensorial and physiological food (ELSEVIER, 2018). The other magazines highlighted, Journal of Agricultural and Food Chemistry, Pakistan Journal of Nutrition and the Journal of The Science of Food and Agriculture have impact factor 3.154 (ACS PUBLICATIONS, 2018); 0.29 (Asian Network for Scientific Information, 2018) and 2,463 (WILEY ONLINE LIBRARY, 2018), respectively.

Following the analysis result was obtained 156 authors published on the species Roselle in various journals. Figure 3 expresses the ranking of the leading writers and the amount of their contributions to the development of scientific research. The first three authors highlighted by the number of publications.

Figure 3 - Number of species H. sabdariffa publications by authors

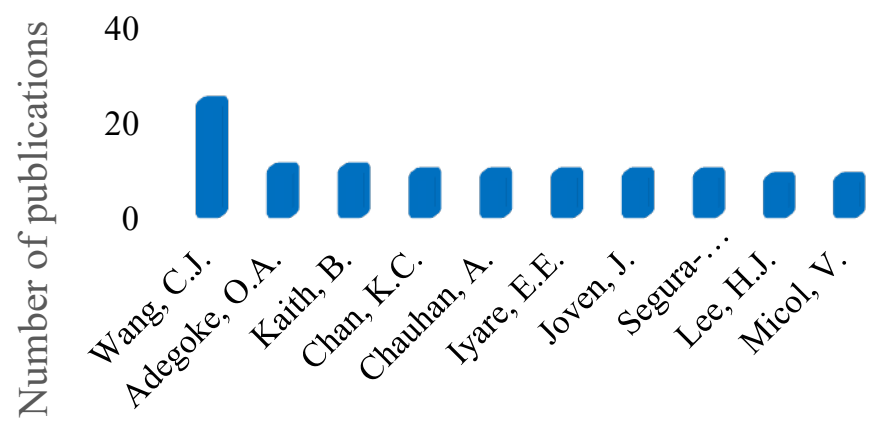

Source: Prepared by the authors of this article (2018)

The first place is occupied by the scientist and publisher with 23 Jong Wang Chau articles produced. Then, with a much less significant amount of 9 articles, were found tied authors $A$. Olajire Adegoke Kaith and B. As defined only these 41 items, searching the database Scopus determined that about $44 \%$ of full documents are applied in the field of Agriculture and Life Sciences and $26 \%$ in the Chemicals sector.

The contributions of Wang Chau Jong and his collaborators found that 11 articles have been published addressing chemical aspects, biochemical and pharmacological species Hibiscus sabdariffa. The author is from Taiwan and develops scientific papers from 1986 to 2017. Still on articles published by Wang, $\mathrm{CJ}$ the last ten years, the main information extracted on the plant under study say about the application of the polyphenolic components of Hibiscus sabdariffa in inhibiting diabetic nephropathy, lowering cholesterol in men and women, oxidative reduction LDL, etc. Such applications are described in the second analysis step of scientific exploration.

The distribution of the territorial level publications is observed in Figure 4. Nigeria (93) and India (84) assume the post of countries with the highest number of articles published in the years 2007 to 2017. Following are Taiwan (36), Egypt (35th), Mexico (35th), Malaysia (31) United States (28), Indonesia (26), Spain (24), China (23), Thailand (23), France (20) and 13th place Brazil with 19 articles. The other countries that have published were not recorded in the graph of Figure 4 given the low proportion of results. 
Figure 4 - Number of species $H$. sabdariffa publications by country

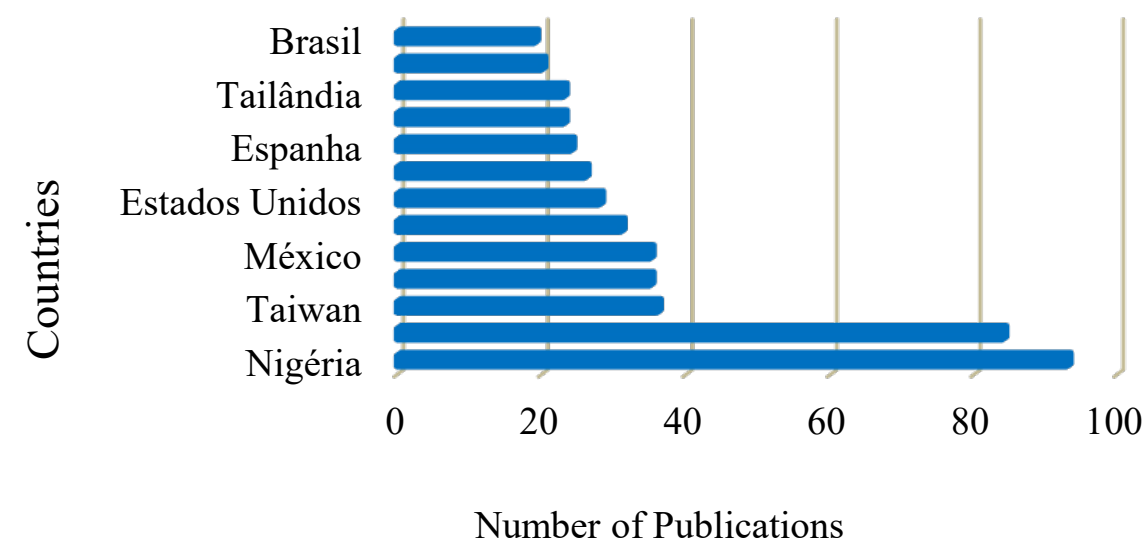

Source: Prepared by the authors of this article (2018)

The cultivation and development of research on the hibiscus in Nigeria and India are for various purposes. Articles found in Scopus, there was a wide application of the species Hibiscus sabdariffa in the development of traditional medicines for the treatment of renal, cardiovascular and muscle diseases, due to the low and middle income in these countries. Thus, approximately $38.9 \%$ (68) of articles published in Nigerian and Indian territory are covered by the area classified as "remedies".

The articles published in Brazil are highlighted in the field of Chemistry, Biochemistry and Molecular Biology with 58\% (11) of the total records. The studies point to the use of hibiscus in folk medicine due to its anti-inflammatory and antioxidant activities. In addition, the plant also appears applied to the weight loss process and protection against liver damage. Through data analysis, we can see an annual performance in the number of gender Hibiscus and Hibiscus sabdariffa species publications from 2007 to 2017 (Figure 5). Taking into account only the 610 articles published on the species, it is possible to observe a significant increase in the development of scientific papers between the years 2011 and 2017.

Figure 5 - Number of publications Hibiscus genus and species H. sabdariffa in the years 2007 to 2017

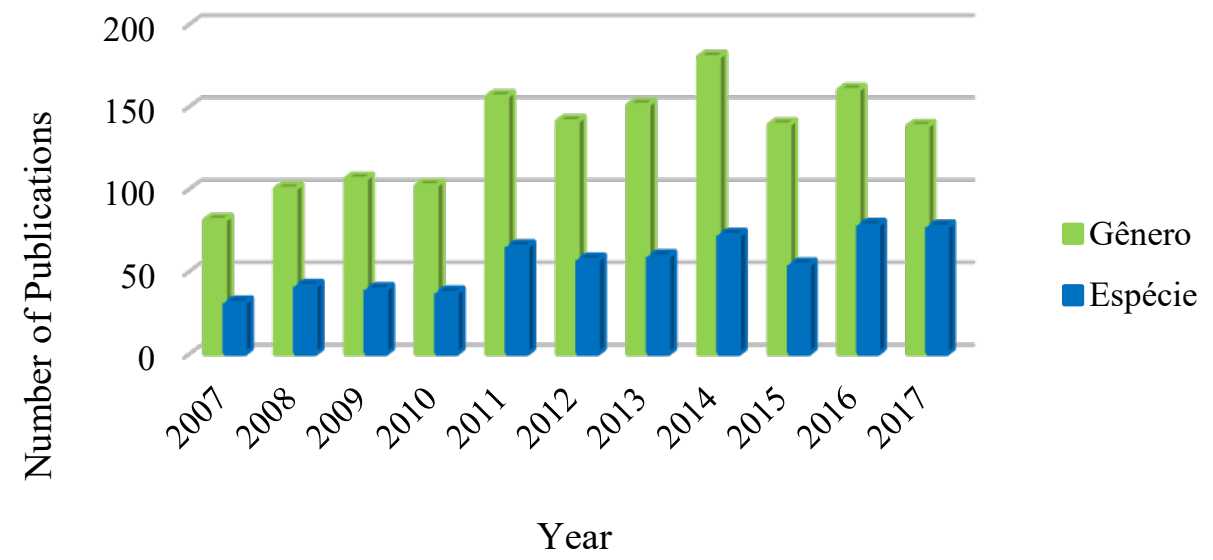

Source: Prepared by the authors of this article (2018)

According to Figure 7, the year with more Hibiscus gender publications corresponds to 2014 with $11 \%$ of the articles. As to the hibiscus species, the highlight of the year was 2016 with $12.8 \%$ 
of the total jobs. The first scientific paper on the species Hibiscus sabdariffa, dates from 1909 and was developed by the author Arthur George Perkin, titled "The coloring matters of the flowers of Hibiscus sabdariffa and Thespasia Lampas" (The color of the flowers of Hibiscus sabdariffa and Thespasia lampas). The article was published in the collection Journal of the Chemical Society and unable to get access to the summary of the work, probably because of the publication date.

The studies in the scientific literature review have ratified the use of hibiscus in folk medicine in the form of teas, wines, vinegars, among other nutritious drinks. The chalice, as expected, is the most sought vegetable part for the preparation of products with various herbal applications. Then, the oil extracted from the seeds is widely applied in the prevention and control of diseases caused by the hypertensive higher LDL (Low Density Lipoprotein) in the body. Painting 1 lists the main medicinal uses of hibiscus reported in scientific papers.

Painting 1 - Major pharmacological activity of $H$. sabdariffa $L$.

$\begin{array}{cc}\text { Pharmacological PROPERTIES } & \text { ReFERENCES } \\ \text { Antioxidant } & \text { Ali et al. (2003) } \\ \text { Antimalarial } & \text { Ali et al. (1991) } \\ \text { Antiatherosclerotic } & \text { Liu et al. (2006) } \\ \text { Antispasmodic } & \text { Ali et al. (1991); Sarr et al. (2009) } \\ \text { Antibacterial/Antifungal/Antiparasitic } & \text { Liu et al. (2006); Fullerton et al. (2011) } \\ \text { Anti-inflammatory } & \text { Kao et al. (2016) } \\ \text { Hepatoprotective } & \text { Liu et al. (2006) } \\ \text { Hypocholesterolemic } & \text { Lin et al. (2006); Gurrola-Diaz et al. (2010) } \\ \text { Uricosuric } & \text { Kao et al. (2016) } \\ \text { Cytotoxic } & \text { Al-Mamun et al. (2011) } \\ \text { Antiobesity } & \text { Gurrola-Diaz et al. (2010) } \\ \text { Diuretic effect } & \text { Alarcon-Alonso et al. (2012); } \\ \text { Antihypertensive } & \text { Ajay et al. (2007) } \\ \text { Chemopreventive effect for cancer } & \text { Liu et al. (2006) }\end{array}$

Source: Prepared by the authors of this article (2018)

The antioxidant property attributed to $H$. sabdariffa the cup was also cited in a number of in vitro studies, in addition to those referenced in Table 2 (HIRUNPANICH et al., 2005; OLALYE; ROCK, 2007; ESA-MOHD et al., 2010). In more recent studies, the antioxidant and anti-inflammatory hibiscus were observed in experiments with methanol extracts of the leaves, in which the presence of bioactive compounds such as caffeic acid and neochlorogenic acid contributed to the performance in reducing oxidative stress in cell models and myeloperoxidase (MPO), the main agents responsible for inflammation (KAPEPULA et al., 2017).

The antibacterial activity of the plant cup proved to be efficient against various bacterial strains in vitro, such as Bacillus stearothermophilus, Micrococcus luteus, Clostridium sporogenes, Bacillus cereus, and Escherichia coli (OLALEYE, 2007). The anti-Escherichia coli effect was confirmed in experiments Paim et al. (2017) applying to different concentrations (5, 10, 20 and $30 \%$ ) of the hydroethanolic extract of $H$. sabdariffa portions of ground meat contaminated with E. coli. logarithmic reduction was obtained in almost all treatments, with the greatest observed result in meat containing $30 \%$ of plant extract. 
According to Table 2, the antispasmodic effect of hibiscus has been analyzed since the 1990s, studies with Ali et al. (1991) have demonstrated that the actions of the same in the control of muscle contractions of the uterus, rat tracheal chain and the diaphragm, which retract pulses. The same property was subsequently observed by Sarr et al. (2009) in inducing the relaxing effect of muscles located in the thoracic region of rats, mainly caused by the biological action of polyphenols present in the vegetable.

The hibiscus extract the cup is also used in reducing hepatic and renal damage induced by toxins in vitro as tiociacetamida (TAA), azitioprina, carbon tetrachloride, cadmium and irradiation (LIU et al., 2006). In this example, the experiment performed with rats laboratories Ezzat et al (2016) demonstrated that the variety of anthocyanins present in $H$. sabdariffa goblets showed hepatoprotective functions including tumor necrosis activity and restore liver structure up to $70 \%$. In another case, the application of the calyx extract with different concentrations of anthocyanins (50, 100 and $200 \mathrm{mg} / \mathrm{kg}$ ) showed the same efficacy as the use of lisonopril (10 $\mathrm{mg} / \mathrm{kg}$ ) in rats with renal diseases caused by high doses adenine (ALI et al., 2017).

Recently, polyphenols hibiscus leaf extracts also showed anticancer activity in the inhibition of prostate tumors in mice (LIN et al., 2012) and anti-hypertensive activity in the control of blood pressure and increased blood vessel diameter (AJAY et al., 2007; INUWA et al., 2012). The result for the search for patents in both analyzed databases, without time limit, was organized and grouped as shown in Table 2. We found eight patents in the national data base INPI (National Institute of Industrial Property), 3 of these, concerning research with the scientific name of the plant and one common name in Brazil. For WIPO international data base (World Intellectual Property Organization), is recorded deposits 2.680196 patents belonging to the species Roselle and only one search on the term "vinegar" which amounts to the same patent filed at the PTO.

Table 2 - Total patents registered in INPI and WIPO technology bases

\begin{tabular}{ccc} 
KEY wORDS & INPI & WIPO \\
Hibiscus & 4 & 2483 \\
Roselle & 3 & 196 \\
Vinegar & 1 & 1 \\
Total & 8 & 2680 \\
\hline
\end{tabular}

Source: Prepared by the authors of this article (2018)

As found in the patents analysis PTO was possible to identify three orders of duplicates related species Roselle. After discarding those applications, only five remaining patents, these being related to the genre 4, 1 and 3 the species to plant species common name.

To describe information data were used as the order code, the date of deposit, the title and CIP patents found in the PTO with the keyword Roselle. In Painting 2, it is observed that the first patent was filed in February 2016 and the second in August 2017.

According to the CIP, are all classified in section A (human needs) with A23D subclasses (oils and edible fats), A61K (preparations for medical, dental or hygienic purposes) and A23L (food, food products or alcoholic beverages; its preparation or treatment). 
Painting 2 - Species Patent Information H. sabdariffa deposited in INPI

\begin{tabular}{cccc} 
ORDER & DEPOSIT & TitLE & CIP \\
$\begin{array}{c}2017 \text { BR10 } \\
0175782\end{array}$ & $08 / 16 / 2017$ & $\begin{array}{c}\text { Compound olive oil extra virgin olive } \\
\text { doped concentrated extract of Roselle }\end{array}$ & A23D 9/007 \\
02017 BR10 & $08 / 10 / 2017$ & $\begin{array}{c}\text { Process of obtaining concentrated liquid extract of } \\
\text { Hibiscus sabdariffa cup for instant preparation of teas, } \\
\text { drinks and other food uses and product thus obtained }\end{array}$ & A61K 36/185 \\
0 2016 BR10 & $02 / 03 / 2016$ & $\begin{array}{c}\text { Functional beverage coconut water and } \\
\text { tea hibiscus (Hibiscus sabdariffa L.) }\end{array}$ & A23L 2/00 \\
\hline
\end{tabular}

Note: PTO, 2018.

Source: Prepared by the authors of this article (2018)

From the results it can be deduced that the lack of investments of the Brazilian government in the development of technological research influences the low number of patents filed in national databases, even with Brazil occupying "[...] the third in the scenario world in the production of vegetables and fruits" (MIRANDA, 2010). When compared to the total of requests for records in other countries, this figure is still far less expressive.

The species Hibiscus sabdariffa is an adaptation of tropical and subtropical plant both in the Southern Hemisphere as the Northern Hemisphere (VIZOTTO; PEREIRA, 2008). According Lewinsohn and Prado (2000), Brazil is the country with the largest amount of tropical forests in the world, with the richest flora on the world stage. However, with respect to the cultivation and study of bioactive substances of hibiscus in Brazil, there are few recommendations or resource investments for the development of patents. Already considered developed countries have more incentives and government applications in advancing research and technological innovation, while not having significant areas for the cultivation of hibiscus, as is the case of Brazil.

With the information collected in the WIPO data base was identified 18 countries with patents on the species Hibiscus sabdariffa internationally, and the main were cast in Figure 6.

Figure 6 - Countries with the patent of $H$. sabdariffa

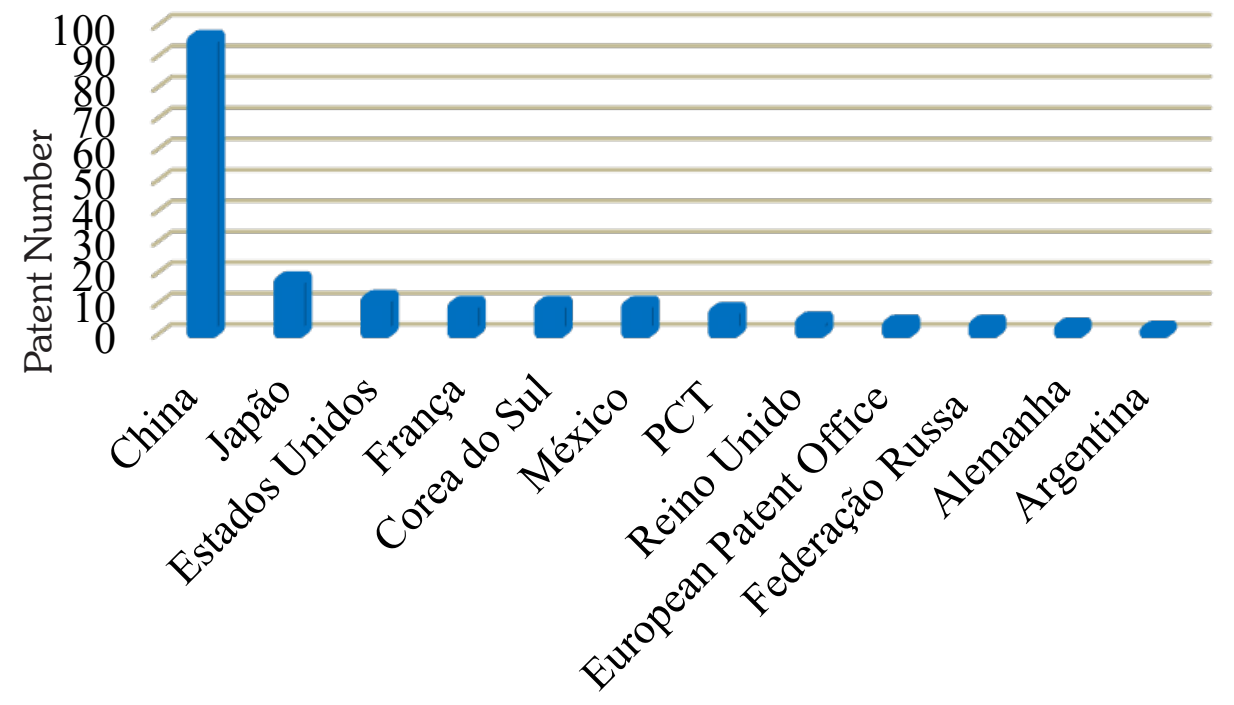

Countries

Source: Prepared by the authors of this article (2018) 
In Figure 6, it is observed that China occupies the first position with 95 and patents dating from 1996 to 2017. This is a significant amount, it represents about $53 \%$ of the total registered and demonstrates the concern of the country in protect their respective research. The second and third position are also occupied by high technological development countries, as is the case of Japan (17) and United States (11). Soon after, are France (9), South Korea (9) Mexico (9), PCT (7), United Kingdom (4), EPO (3) Russian Federation (3), Germany (2) and Argentina (1).

The first patent on the Hibiscus species sabdariffa registered with WIPO, was filed in October 1945 in Britain and CIP C12P7/52, it is classified in section C (Chemistry; Metallurgy) and C12P subclass (processes or fermentation processes using enzymes to synthesize a composition/desired chemical compound or to separate optical isomers from a racemic mixture). Subsequently, the second and third deposits were made in the 1980s in France and in 1996 in China. The annual growth of patent applications by the year 2017 is shown in Figure 7.

Figure 7 - Number of species H. sabdariffa patents filed per year

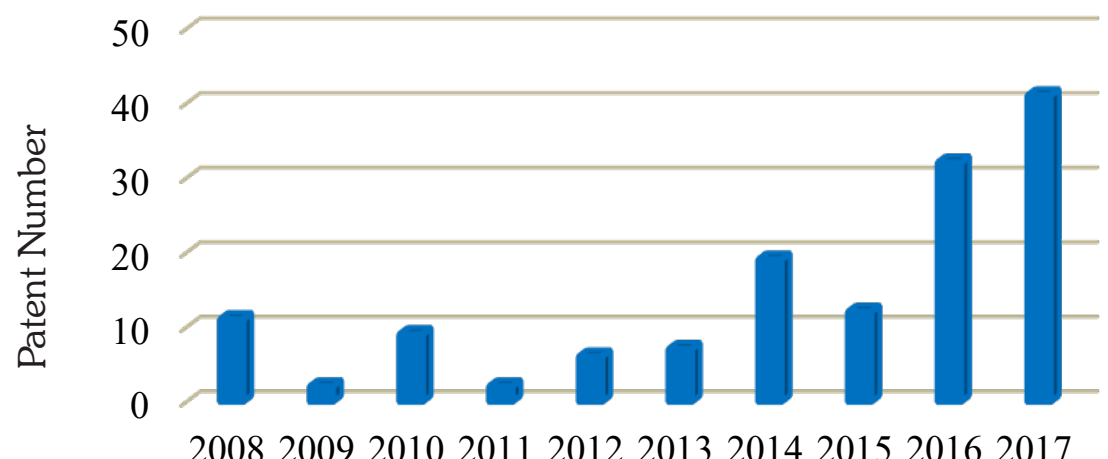

Year

Source: Prepared by the authors of this article (2018)

As noted in Figure 7, the amount of deposits for the years 2016 and 2017 stood out compared to previous periods, and take $41.5 \%$ of the total registrations until the last given year to search. The amount of 73 patents recognized in the interval, 69 were requests made by China, accounting for $91 \%$ of the documents and highlighting once again the participation of the Chinese government investment of technological research on the species Hibiscus sabdariffa.

According to Gomes (2018), the patent acts as a key tool for companies to ensure protection to the creation and development of their products, in addition, also allows the inventor has full coverage of investigative aspects of the invention. In this context, this research identified 10 major depositors companies patent the species Hibiscus sabdariffa in the data base WIPO (Figure 11).

First, with 4 documents is a US company Mary Kay Intouch with patents distributed in A61Q subclasses (specific use of cosmetics or similar preparations for personal hygiene) and A61K (preparations for medical purposes, dental or hygienic). This company was established in honor of founder Mary Kay Ash and aims at the development of "products in the categories makeup, skin care and fragrances". 
Figure 8 - Major companies holding patents of the species H. sabdariffa

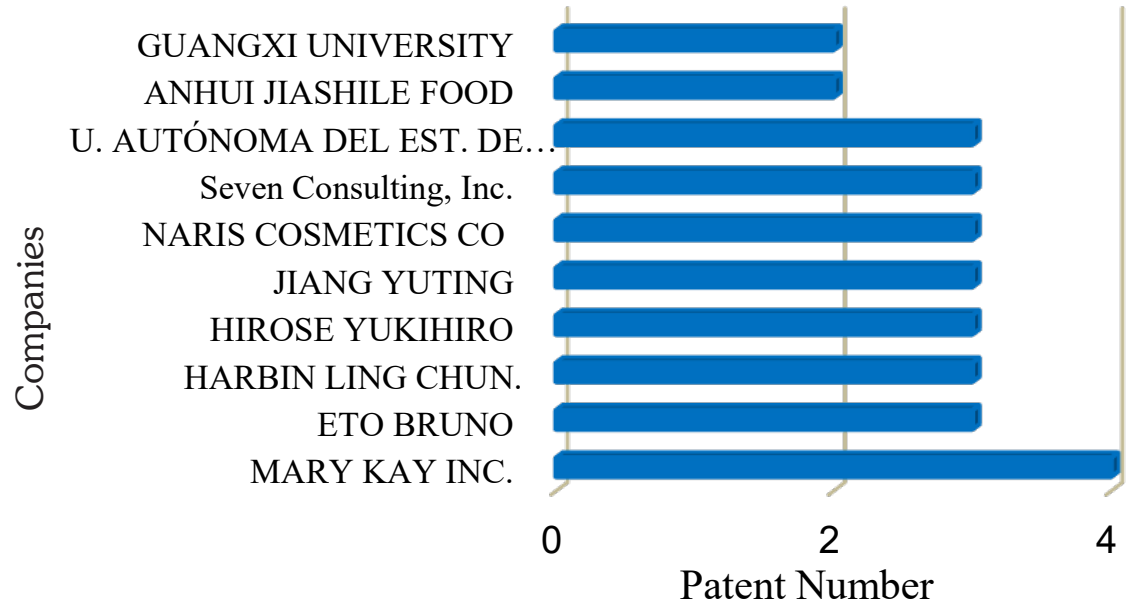

Source: Prepared by the authors of this article (2018)

Following with three papers each, we highlight companies/Chinese institutions (Harbin Ling Chun Wei Dao Food Development CO and Jiang Yuting), Japanese (Hirose Yukihiro and Naris Cosmetics CO), French (ETO Bruno), American (Seven Consulting, Inc) and Mexican (Universidad Autonoma Del State of Hidalgo). Finally, in third place with two documents each, are the company Anhui Jiashile Food Processing CO and Guangxi University.

CIP facilitates the search patent databases in technological therefore ranks according to the application. For analytical information was taken into consideration the fact that a given patent may have more than one classification. According to Figure 9 and based on the CIP is possible to identify the organization of patents related to Hibiscus sabdariffa species found in the WIPO database. The graph of this figure provides results regarding the section, class and subclass. Thus, it is observed that most patents have been framed in the section on human needs, and partly in section $\mathrm{C}$, on the application in chemistry and metallurgy.

Figure 9 - Rate of patents regarding the CIP parameters

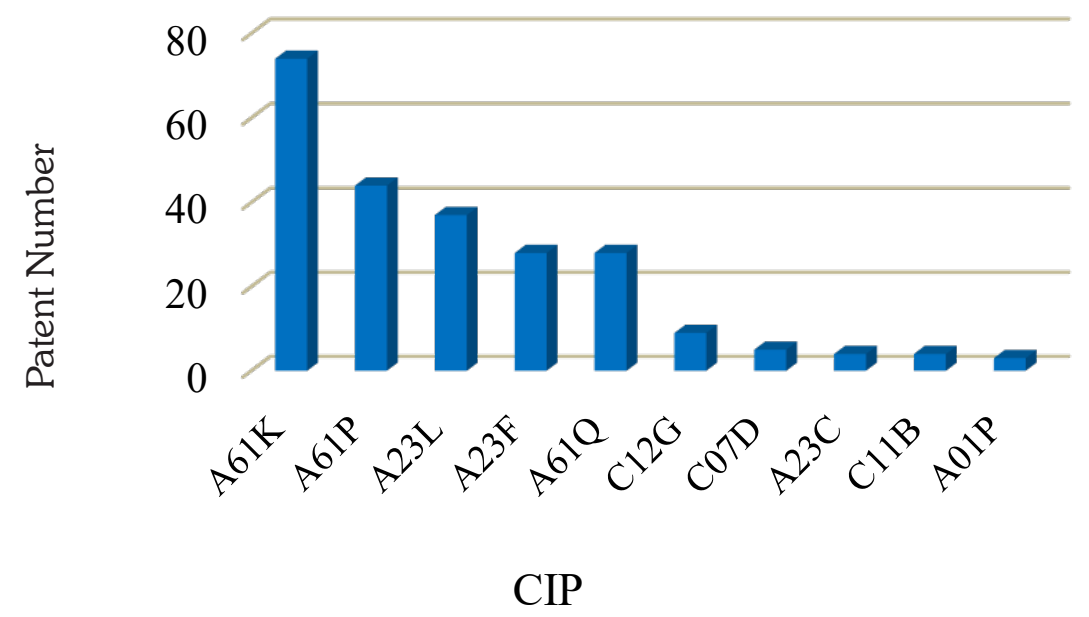

Source: Prepared by the authors of this article (2018)

The classes identified in section A were A61 (preparations for medical purposes, or dental hygiene) as 146 patent, i.e., about $67 \%$ of the total found; A23 (its food and food products, its 
processing) with 69 patents representing 31\% in terms of percentage; A01 (agriculture, forestry, animal husbandry, hunting, capture traps, fishing) with only 3 patents. In section $\mathrm{C}$ the following classes were recorded: C12 (Biochemistry, beer, alcohol, wine, vinegar, microbiology, enzymology, genetic engineering or mutation) with 9 patents; C07 (organic chemistry) with 5 patents; C11 (animal or vegetable oils, fats, greases or waxes substances, fatty acid derivatives thereof, detergents, candles) 4 patent.

To describe in more detail about the present patent subclasses, these were arranged as shown in Table 4.

Painting 3 - Subclasses found in patents on the species H. sabdariffa

SubCLASS CIP

A01P

A23C

A23F

A23L

A61K

A61P

A61Q

C07D

C11B

C12G

\section{TitLe/NAmE}

Activity of chemical compounds or preparations biocides, pest repellents or attractive or plant growth regulators.

Dairy products, eg milk, butter, cheese; milk or cheese substitutes; production thereof.

Coffee; tea; their substitutes; manufacture, preparation, or infusion thereof.

Coffee; tea; their substitutes; manufacture, preparation, or infusion thereof; its preparation or treatment, eg cooking, modification of nutritive qualities, physical treatment; food storage or food products in general.

Preparations for medical, dental and hygienic purposes.

Specific therapeutic activity of chemical compounds or medicinal preparations.

Specific use of cosmetics or similar preparations for personal hygiene.

Heterocyclic compounds.

Production, p. Ex. For raw materials compression or extraction from waste substances, refining or preserving oils, fatty substances, eg lanolin, fatty oils or waxes; essencial oils; Perfumes.

Note: INPI, 2018.

Source: Prepared by the authors of this article (2018)

Upon significant number of patents found and applied for medical purposes preparations, or dental hygiene $(\mathrm{A} 61 \mathrm{~K})$, explored recent inventions is framed that axis. Among them is an application filed in the year 2017 and the number WO2017105211, which uses an extracted stem hibiscus acid and derivatives thereof for use in microbiology, combating resistant bacteria in vivo or inert medium. The KR1020160114305 identification of the invention, and also classified in IPC A61K refers to a cosmetic product developed in South Korea and produced from the extract of polyphenols present in Hibiscus sabdariffa that controls the temperature of the skin, preventing premature aging.

Another highlight in A61K classification, the patent was filed in 2012 by the Mexican Social Security Institute in Mexico under MX2012010586 protocol code. In developing this research, the inventors Alejandro Zamilpa Alvarez, Aime Tortoriello Garcia and co-workers created a product based on the aqueous extract of Hibiscus sabdariffa with acetonitrile, methanol, which is applied in the control of certain muscle diseases such as renal failure, myocardial infarction and stroke brain. In the field of specific products with therapeutic activity of chemical compounds or medicinal preparations, that is, A61P classification emphasizes the CN105695102 protocol 
patent, filed in the year 2016. It is more of a patented research by a Chinese institution, South China University of Technology (University of Technology of South China), which through a steam separation method, obtained the oil Hibiscus sabdariffa, which is used in the preparation of anti-inflammatory drugs.

Compared CIP A61P research, it identified an important invention in the treatment and inhibition of cancer from Roselle. The product was prepared in May 2008 by Wang Chau-Jong in the United States, with number US20080113050 protocol. The patent refers to the extraction of anthocyanins from hibiscus for cancer treatment in patients with infection. To subclass A23L patent, met important technological research in the application of hibiscus in preparation and conservation of nutritious drinks. This is the case of CN201610898360.7 protocol patent, filed by China in 2016, which uses Hibiscus sabdariffa, honeysuckle leaves, mint stalks and Fructus momordicae in the preparation of a tea that can restore consciousness, calm the nerves, remove blood poison, reduce blood fat and blood pressure and scavenge free radicals.

Another case encountered is the PH22014000449 protocol research conducted in 2014 in the Philippines, which involves the production process Rosélia powder (Hibiscus sabdariffa), a rich source of nutrients such as vitamin $\mathrm{C}$ and anthocyanin, which can be applied as coloring or flavoring food drink. With respect to subclass C12G, he stood out in another patent filed by China in the year 2017 under number CN201611215172.6 protocol. The invention relates to a wine made from the Hibiscus sabdariffa fruit, which prevents the accumulation of fat on the inner walls of the arteries, thus preventing strokes, heart attacks and others.

\section{Conclusions}

Overall overview of scientific prospecting most publications related to Hibiscus sabdariffa L. species were applied in the field of Pharmacology, Toxicology and Pharmacy and began to evolve considerably from the year 2011 until the year 2017, showing thus a breakthrough in number of searches related to the plan for the years that follow. Nigeria, followed by India and Taiwan were considered the countries that published on hibiscus in the last ten years.

Regarding the aforementioned pharmacological activities, polyphenols and anthocyanins concentrated in goblets, leaves and hibiscus seeds, had high medicinal potential in the prevention and treatment of diseases. Monitoring of technological exploration, China is the largest holder of patents. Thus, it is a country that demonstrates concern on issues related to intellectual property developed in research companies/institutions own. On the other hand, Brazil presented results from low proportions in the field of scientific publications in the field of patented products, reflecting the lack of government investment in S \& T research (Science and Technology).

With regard to the IPC classification code, patents found eligible in sections $\mathrm{A}$ and $\mathrm{C}$, with most of them included in subclass A61K. Thus, it can be stated that, as is described in scientific publications, the main application of Hibiscus sabdariffa L. species is in activities with medicinal and pharmaceutical purposes. Considering the fact that the more techniques are discovered, the greater the possibility of building new knowledge, this research was relevant and innovative as through prospective studies, the knowledge collected on the Hibiscus sabdariffa L. species can serve as a base for researchers who want to develop innovative work or just get information on 
the characteristics, chemical composition and pharmacological properties of the plant, in addition to providing an overview on the scientific advances this line of research.

\section{References}

AJAY, M. et al. Mechanisms of the anti-hypertensive effect of Roselle L. calyces. Journal of Ethnopharmacology, [S.I.], v. 109, n. 3, p. 388-393, 2007.

ALARCÓN-ALONSO, J. et al. Pharmacological characterization of the diuretic effect of Hibiscus sabdariffa Linn (Malvaceae) extract. Journal of Ethnopharmacology, [S.I.], v. 139, n. 1, 751-756, 2012.

ALI, B. H.; WABEL, N. A.; BLUNDEN, G. Phytochemical, Pharmacological and Toxicological Aspects of Hibiscus sabdariffa L.: A review. Phytotheraphy Research, [S.l.], v. 19, p. 369-375, 2005.

ALI, B. H. et al. Effect of aqueous extract of anthocyanins and calyces of Roselle (Malvaceae) in rats with adenine-induced chronic kidney disease. Journal of Pharmacy and Pharmacology, [S.l.], v. 69, n. 9, p. 1.219-1.229, 2017.

ALI, M. B. et al. Investigation of the potential of Roselle calyces. Journal of Ethnopharmacoly, [S.l.], v. 31, n. 2, p. 249-257, 1991.

AL-MAMUN, A. et al. In vitroevaluation of the antibacterial, cytotoxic and insecticidal activities of Hibiscus sabdariffafruits. Libyan Agriculture Research Center Journal Internation, [S.I.], v. 3, n. 1, 144-149, 2011.

AL-MAMUN et al. In vitro Evaluation of the Antibacterial, Cytotoxic and Insecticidal Activities of Hibiscus sabdariffa Fruits. Libyan Agriculture Research Center Journal Internation, [S.l.], v. 2, n. 3, p. 144-149, 2011.

CARDOSO, M. O. Vegetables unconventional Amazon. Brasília, DF: Embrapa-SPI. 1997.

CORADIN, L.; SIMINSKI, A.; REIS, A. Native species of flora of current or potential economic value: plans for the future. Brasilia, DF: South Region Brasilia. 2011.

EZZAT, S. M. et al. Metabollic profile and hepatoprotective activity of the anthocyanin-rich extract of Hibiscus sabdariffa calyces. Pharmaceutical Biology, [S.I.], v. 54, n. 12, p. 3.172-3.181, 2016.

FULLERTON, M. S. C. et al. Determination of antioxidant contents in red sorrel and its anticarcinogenic potential in azoxymethane-induced colonic aberrant crypt foci. Research Journal of Phytochemistry, [S.l.], v. 2, n.1, p. 69-76, 2008.

GALVÃO, M. C. B. The bibliographic and scientific research. epidemiology fundamentals. 2018. 2nd ed. The 398, 1-377. Available at: http://www2.eerp.usp.br/Nepien/DisponibilizarArquivos/ Levantamento_bibliografico_CristianeGalv.pdf. Access: 15 Feb. 2019.

GOMES, F. Understand the importance of patents for the creative industry. 2018. Available at: http://fgmarcas.com.br/entenda-a-importancia-das-patentes-para-a-industria-criativa-2/. Access: 10 Mar. 2019.

GURROLA-DIÁZ, C. M. et al. Effects of Hibiscus sabdariffa extract powder and preventive treatment (diet) on the lipid profiles of patients with metabolic syndrome (MeSy). Phytomedicine, [S.I.], v. 17, n. 1, p. 500-505, 2010. 
HERRERA-ARELLANO, A. et al. 2007. Clinical effects produced by the standardized herbal medicinal product of Roselle on Patients with hypertension. A randomized, double-blind, Lisinoprilcontrolled clinical trial. Planta Medica, [S.l.], v. 73, p. 6-12, 2007.

HIRUNPANICH, V. et al. Antioxidant effects of aqueous extracts from dried calyx of Hibiscus sabdariffa Linn. (Roselle) in vitro using rat low-density lipoprotein (LDL). Biological \& Pharmaceutical Bulletin, [S.1.], v. 28, n. 3, p. 481-484, 2005.

INPI - INSTITUTO NACIONAL DA PROPRIEDADE INDUSTRIAL. Patent Classification. 2018. Available at: http://www.inpi.gov.br/menu-servicos/patente/classificacao-de-patentes. Access: 11 Feb. 2019.

INUWA, I. et al. Longterm ingestion of Roselle calyx extract Enhances myocardial capillarization spontaneously hypertensive rat in the. Experimental Biology and Medicine, (Maywood), v. 237, n. 5, p. 563-569, 2012.

ISMAIL, A.; IKRAM, E. H. K; NAZRI, H. S. M. Roselle (Hibiscus sabdariffa L.) seeds nutritional composition protein quality and health benefits. Food, [S.l.], v. 2, n. 1, p. 1-16, 2008.

KAO, E. S. et al. Polyphenolic extract from Hibiscus sabdariffa reduces body fat by inhibiting hepatic lipogenesis and preadipocyte adipogenesis. Food Funct, [S.I.], v. 7, n. 1, p. 171-182. DOI: 10.1039/ c5fo00714c.

KAPEPULA, P. M. ${ }^{1}$. Comparison of bioactivities and metabolic profiles of the leaves of three Congolese Hibiscus edible species. Natural Product Research, [S.l.], v. 31, n. 24, p. 2.885-2.892, 2017.

LEWINSOHON, T. M.; PRADO, P. I. Brazilian Biodiversity: Current State of Knowledge Synthesis. 2018. Available at: http://www.mma.gov.br/port/sbf/chm/doc/estarte.doc. Access: 2 Mar. 2018.

LIN, T. et al. Hibiscus sabdariffa extract angiograms serum cholesterol in men and women. Nutrition Research, [S.I.], v. 27, n. 3, p. 140-145, 2007.

LIU, J. Y. et al. The protective effects of Hibiscus sabdariffa extract on CCl4-induced liver Brosis in rats. Food and Chemical Toxicology, [S.I.], v. 44, p. 336-343, 2006.

LORENZI, H.; MATOS, F. J. A. Medicinal Plants in Brazil, Native and Exotic. Plantarum Institute of Plant Studies LTDA. São Paulo, 2002.

MOHAMMED, A. et al. Roselle (Hibiscus sabdariffa) seed oil is a rich source of (-) tocopherol. Journal of Food Science, [S.I.], v. 72, p. 207-211, 2007.

MOHD-ESA, N. et al. Indifferent parts Antioxidant activity of roselle (Hibiscus sabdariffa L.) extracts and exploitation potential of the seeds. Food Chemistry, [S.I.], v. 122, n. 4, 1.055-1.060, 2010.

MORTON, J. F. Roselle. In: Fruits of warm climates. Miami, USA: Florida Flair Books, 1987. p 2.081-2086.

OLALEYE, M. T. Cytotoxicity and antibacterial activity of Methanolic extract of Hibiscus sabdariffa. Journal of Medicinal Plants Research, [S.I.], v. 1, n. 1, p. 9-13, 2007.

OLALYE, M. T.; ROCK, J. B. Commonly used medicinal plants tropical exhibit distinct in vitro antioxidant activities against hepatotoxins in rat liver. Experimental and Toxicologic Pathology, [S.I.], v. 58, n. 6, 433-438, 2007. 
PAIM, M. P. et al. Anti-Escherichia coli effect of Roselle L. In the meat model. Food Science and Technology, [S.1.], v. 37, v. 4, p. 647-650, 2017.

SARR, M. et al. In vitro vasorelaxation mechanisms of bioactive compounds extracted from Roselle on rat thoracic aorta. Nutrition \& Metabolism, [S.I.], v. 6, n. 45, p. 1-12, 2009.

\section{Sobre os Autores}

\section{Katiury Castro Cavalcante}

E-mail: katiurycavalcante@hotmail.com

Licenciada em Química pelo Instituto Federal de Educação, Ciência e Tecnologia do Maranhão - Campus Codó (IFMA).

Endereço profissional: Povoado Poraquê, s/n, Zona Rural, Codó, MA. CEP: 65040-080.

\section{Gladson Diniz Pinheiro}

E-mail: gladsonpinheiro@gmail.com

Licenciado em Química pelo Instituto Federal de Educação, Ciência e Tecnologia do Maranhão - Campus Codó (IFMA).

Endereço profissional: Povoado Poraquê, s/n, Zona Rural, Codó, MA. CEP: 65040-080.

\section{Álvaro Itaúna Schalcher Pereira}

E-mail: alvaro.pereira@ifma.edu.br

Doutor em Engenharia e Ciências de Alimentos, Mestre em Química Analítica e Químico. Professor do Instituto Federal de Educação, Ciência e Tecnologia do Maranhão - Campus Codó (IFMA).

Endereço profissional: Povoado Poraquê, s/n, Zona Rural, Codó, MA. CEP: 65040-080.

\section{Oswaldo Palma Lopes Sobrinho}

E-mail: oswaldo-palma@hotmail.com

Engenheiro Agrônomo pelo Instituto Federal de Educação, Ciência e Tecnologia do Maranhão - Campus Codó (IFMA). Mestrando em Ciências Agrárias, Agronomia pelo Instituto Federal de Educação, Ciência e Tecnologia Goiano, Campus Rio Verde (IF Goiano).

Endereço profissional: Rodovia Sul Goiana, km 1, Zona Rural, Rio Verde, GO. CEP: 75901-970.

\section{Layane Bastos dos Santos}

E-mail: layane.santos@ifto.edu.br

Psicóloga, Mestranda em Educação Profissional e Tecnológica (EPT) em Rede Nacional pelo Instituto Federal de Educação, Ciência e Tecnologia do Maranhão (IFMA), Campus São Luís/Monte Castelo.

Endereço profissional: Instituto Federal de Educação, Ciência e Tecnologia do Tocantins, Campus Araguatins. km 7, s/n, Povoado Santa Tereza, Araguatins, TO. CEP: 64077-300.

\section{Francisco Adelton Alves Ribeiro}

E-mail: adelton@ifma.edu.br

Doutor em Biotecnologia (RENORBIO/UFPI). Mestrado em Engenharia da Computação e Sistemas (UEMA).

Professor do Instituto Federal de Educação, Ciência e Tecnologia do Maranhão, Campus Codó (IFMA).

Endereço profissional: Povoado Poraquê, s/n, Zona Rural, Codó, MA. CEP: 65040-080. 